\title{
Enhancing effect of nitrogen on grain production of hybrid maize in Chitwan valley
}

\author{
B H Adhikary ${ }^{1}$ and R Adhikary ${ }^{2}$ \\ ${ }^{1}$ Communication, Publication and Documentation Division, NARC, Khumaltar, Lalitpur \\ ${ }^{2}$ Institute of Agriculture and Animal Science, Tribhuvan University, Lamjung Campus
}

\begin{abstract}
Nitrogen is one of the key factors for increased grain production of hybrid maize. A newly developed hybrid maize variety Rampur Hybrid-2 was evaluated for grain production by the application of different levels of nitrogen $(60,120$ and $180 \mathrm{~kg} \mathrm{~N} / \mathrm{ha})$ at varying plant densities (55555, 66666 and 83383 plants/ha) along with $60 \mathrm{~kg} \mathrm{P}_{2} \mathrm{O}_{5}$ and $40 \mathrm{~kg} \mathrm{~K}_{2} \mathrm{O}$ /ha in the acidic soil (pH 5.3) of National Maize Research Program, Rampur, Chitwan during the years of 2008/09 and 2009/10. Factorial randomized complete block design (RCBD) with three replications was the design of experiment. The crop was planted at the plot size of $18 \mathrm{~m}^{2}(3.6 \mathrm{~m} \times 5 \mathrm{~m})$. maize was planted in the month of September and harvested in February. The result indicated a sharp response of nitrogen application to this crop whereas the effect of density was observed to be non-significant. Two years mean yield results showed that highest grain yield $(11.10 \mathrm{t} / \mathrm{ha})$ was recorded when the crop was supplied with $180 \mathrm{~kg}$ nitrogen and with 83383 plants /ha followed by the crop supplied with $120 \mathrm{~kg} \mathrm{~N} / \mathrm{ha}$ and 66,666 plant population (10.69 t/ha). The experimental results revealed that application of high dose of $\mathrm{N}(180 \mathrm{~kg} \mathrm{~N} / \mathrm{ha})$ could help increase hybrid maize grain production in the acidic soils of Chitwan valley.
\end{abstract}

Key words : grain yield, hybrid maize, plant densities, nitrogen rates and significant effect

\section{Introduction}

Maize (Zea mays L.) is one of the leading crops in Nepalese agriculture economy. It can be used as food and feed. The increasing demand of maize as food and feed has forced to produce higher yield from an unit area of land and traditional varieties cannot meet the demand so hybrid maize can only fulfill the demand if they are supplied with adequate amount of fertilizers, adequate irrigation and planted at proper densities because they have higher genetic potential of producing more grains compared to those of OPVs (composite) and local varieties. The crop varieties, mainly hybrids, optimum planting date and plant population, water management and combination of desirable practices could influence the response and efficiency of nitrogen given to maize crop. Modern crop hybrids have been bred for increased tolerance to high population and optimum yield can only be obtained near the optimum population (Swanson et al.1973). Singh (1983) suggested maize plant population of 60-65 thousands $\mathrm{ha}^{-1}$ at harvest to attain maximum yield from OPVs. He further suggested that hybrids and composite varieties exhibit their full yield potential only when supplied with adequate quantities of plant nutrient at proper time. A crop of maize yielding about 14 tons of dry matter takes up approximately $161 \mathrm{~kg} \mathrm{~N}, 34 \mathrm{~kg} \mathrm{P}$ and $110 \mathrm{~K} \mathrm{~kg} / \mathrm{ha}$. The need of fertilizer application mainly depends on the type of varieties and plant densities /ha and soil fertility status of 
growing areas. Incoming solar radiation interception is influenced by the crop leaf area so as to achieve complete ground cover. This can be attained by manipulating plant densitity and its distribution over the land surface. Koirala et al. (1977) reported that plant densities of maize could be increased up to 66000 plants/ha. Under soloculture short duration variety (Arun-2) did better under high plant population (90,000 plants /ha) (Sen and Sthapit, 1982). An experiment was conducted at NMRP, Rampur to evaluate the effect of $\mathrm{N}$ levels on maize planted at varying densities. The yield results showed that Hill Pool White variety (HPW) responded positively upto $120 \mathrm{~kg} \mathrm{~N} /$ ha with higher productivity and there was to extra benefit to put extra $\mathrm{N}$ than this level in Rampur condition. Adhikary et al. (2004) reported that highest grain yield of $5284 \mathrm{~kg} / \mathrm{ha}$ could be obtained when HPW was supplied with $120 \mathrm{~kg} \mathrm{~N}$ at the density of 55,333 plants /ha. The hybrid Gaurav produced the highest grain yield of $(8.63 \mathrm{t} / \mathrm{ha})$ at this number of plant population when fertilized with $180 \mathrm{~kg} \mathrm{~N} / \mathrm{ha}$. Adhikary and Baral (2010) reported that highest grain yield (12.16 t /ha) was produced when this hybrid was supplied with $120.60 .40 \mathrm{NPK} \mathrm{kg} / \mathrm{ha}$ and 10 ton of FYM with the cop planted at the population of 83383 plants /ha. There is a need to improve the productivity of maize in order to maintain food balance in the hills (Sharma et al., 2004). Therefore, it is only the way to introduce or develop hybrids which can produce higher grain yield compared to those of OPVs, composite and local varieties when hybrids are supplied with adequate quantities of nutrients, adequate irrigation and with proper plant density maintenance.

The objective of this study was to evaluate the effect of adequate dose of nitrogen and plant densities for increasing grain yield of hybrid maize Rampur Hybrid which was a cross between RML-4/NML-2, in acidic soil condition of Chitwan, Nepal. .

\section{Methodology}

Rampur Hybrid-2 maize was planted at varying plant densities using different levels of nitrogen in the acidic soil condition of NMRP farmland during the two consecutive years 2008/09 and 2009/10. A factorial RCB design was employed in the experiments. Three levels of nitrogen $(60 \mathrm{~kg}=\mathrm{N} 1,120$ $\mathrm{kg}=\mathrm{N} 2$ and $180 \mathrm{~kg} \mathrm{~N} / \mathrm{ha}=\mathrm{N} 3$ ) were applied. Phosphorus and potassium fertilizers at 60 and $40 \mathrm{~kg}$ $\mathrm{P}_{2} \mathrm{O}_{5}$ and $\mathrm{K}_{2} \mathrm{O}$ and $10 \mathrm{t} /$ ha of compost were applied basally in all the plots, respectively. The crop was planted in a plot size of $18 \mathrm{~m}^{2}(3.6 \mathrm{~m} \times 5 \mathrm{~m})$ at the spacing of $60 \mathrm{~cm}$ row to row distance, and 20 $\mathrm{cm}$ (D1), $25 \mathrm{~cm}$ (D2) $\mathrm{cm}$ and $30 \mathrm{~cm}$ (D3) plant to plant distance in a row. The crop was planted in the month of September in the year 20078/09 and 2009/10. Soil samples were analyzed before crop planting and after the crop harvest following Kjeldahl digestion method for $\mathrm{N}$ analysis, Bray II method for P and Spectro fotometer for potash analysis,. All growth and yield parameters taken into study were analyzed statistically. The following treatments were used in the experiments.

Table 1. Treatments combination

\begin{tabular}{clll}
\hline Treatment & $\begin{array}{l}\text { Treatment } \\
\text { combination }\end{array}$ & Remarks & Spacing \\
\hline $\mathrm{T} 1$ & $\mathrm{D}_{1} \mathrm{~N}_{1}$ & 55,555 plants $/ \mathrm{ha}$ and $60 \mathrm{~kg} \mathrm{~N} / \mathrm{ha}$ & $30 \mathrm{~cm} \times 60 \mathrm{~cm}$ \\
$\mathrm{~T} 2$ & $\mathrm{D}_{1} \mathrm{~N}_{2}$ & $55,555 \mathrm{plants} / \mathrm{ha}$ and $120 \mathrm{~kg} \mathrm{~N} / \mathrm{ha}$ & \\
$\mathrm{T} 3$ & $\mathrm{D}_{1} \mathrm{~N}_{3}$ & $55,555 \mathrm{plants} / \mathrm{ha}$ and $180 \mathrm{~kg} \mathrm{~N} / \mathrm{ha}$ & \\
$\mathrm{T} 4$ & $\mathrm{D}_{2} \mathrm{~N}_{1}$ & $66,666 \mathrm{plants} / \mathrm{ha}$ and $60 \mathrm{~kg} \mathrm{~N} / \mathrm{ha}$ & $25 \mathrm{~cm} \times 60 \mathrm{~cm}$ \\
$\mathrm{~T} 5$ & $\mathrm{D}_{2} \mathrm{~N}_{2}$ & $66,666 \mathrm{plants} / \mathrm{ha}$ and $120 \mathrm{~kg} \mathrm{~N} / \mathrm{ha}$ & \\
\hline
\end{tabular}


Agronomy Journal of Nepal (Agron JN) Vol. 3. 2013

\begin{tabular}{clll}
\hline Treatment & $\begin{array}{l}\text { Treatment } \\
\text { combination }\end{array}$ & Remarks & Spacing \\
\hline $\mathrm{T} 6$ & $\mathrm{D}_{2} \mathrm{~N}_{3}$ & 66,666 plants /ha and $180 \mathrm{~kg} \mathrm{~N} / \mathrm{ha}$ & \\
$\mathrm{T} 7$ & $\mathrm{D}_{3} \mathrm{~N}_{1}$ & 83,383 plants $/ \mathrm{ha}$ and $60 \mathrm{~kg} \mathrm{~N} / \mathrm{ha}$ & $20 \mathrm{~cm} \times 60 \mathrm{~cm}$ \\
$\mathrm{~T} 8$ & $\mathrm{D}_{3} \mathrm{~N}_{2}$ & 83,383 plants $/ \mathrm{ha}$ and $120 \mathrm{~kg} \mathrm{~N} / \mathrm{ha}$ & \\
$\mathrm{T} 9$ & $\mathrm{D}_{3} \mathrm{~N}_{3}$ & 83,383 plants /ha and $180 \mathrm{~kg} \mathrm{~N} / \mathrm{ha}$ & \\
\hline
\end{tabular}

\section{Results and discussion}

\section{Effects of nitrogen rates and plant densities on the growth and yield parameters of Rampur Hybrid-2}

Growth results revealed that the effect of plant densities on straw yield, plant height and kernel numbers were found to be non- significant in the year 2008/09, where as its effect on ear height and ear length was observed to be significant. The highest straw yield of 8.84 ton ha ${ }^{-1}$ was recorded when the crop was supplied with $120 \mathrm{~kg} \mathrm{~N}$ and with population of 83,383 plants /ha (Table 2) which was observed to be non-significantly different to other plant densities. Similarly the effect of nitrogen on growth of maize plant was observed to be non-significant during the year 2008/09 (Figure 1). On the other hand, the effect of plant densities on ear height, ear length, kernel rows and stover yield was observed to be non significant in the following year 2009/10 (Table 3). The tallest plant height of $177.6 \mathrm{~cm}$ was recorded when the crop was supplied with $180 \mathrm{~kg} \mathrm{~N} / \mathrm{ha}$ and with the plant density of 83,383 plants/ha which was highly significantly different to other densities. The shortest plant height of $148.6 \mathrm{~cm}$ was recorded with the $60 \mathrm{~kg} \mathrm{~N}$ and with plant density of 55,555 plants /ha (Figure 2). Similarly other plant growth and yield parameters such as ear height, ear length, kernel rows and straw yield were found to be non-significant in the year 2009/10 (Figure 2). On the contrary, the effect of nitrogen on most of growth and yield parameters were observed to be highly significant. The highest stover yield of $9.1 \mathrm{t} / \mathrm{ha}$ was recorded when this crop was supplied with $120 \mathrm{~kg} \mathrm{~N}$ and 66,666 plants /ha (Table 3). The highest kernel number (33.06) was recorded when the crop was supplied with $180 \mathrm{~kg} \mathrm{~N}$ and 83,383 plants /ha (T9, Table 3) which was observed to be highly significant.

\section{Effect of nitrogen and density on the grain production of Rampur Hybrid-2}

The effect of density on 1000 grain weight during the years 2008 and 2009 found to be significant where as its effect on grain yield was observed to be non significant for both years (Table 4). On the other hand, the effect of nitrogen on 1000 grain wt. and grain yield was found to be highly significant for both years. The interaction effect of $\mathrm{N}$ and $\mathrm{D}$ was observed to be non significant. It is noticed that the highest grain yield $(10.16 \mathrm{t} / \mathrm{ha})$ was recorded when the crop was supplied with 180 $\mathrm{kg} \mathrm{N}$ and at plant population of 83,383 plants /ha in the year 2008/09 followed by the crop supplied with $180 \mathrm{~kg} \mathrm{~N}$ and 66,666 plants /ha (Figure 3). In the following year (2009/10), the highest grain yield of $12.16 \mathrm{t}$ /ha was recorded when the crop was supplied with $120 \mathrm{~kg} \mathrm{~N}$ and 83,383 plants /ha followed by $120 \mathrm{~kg} \mathrm{~N}$ and 66,666 plants /ha (T5, Figure 3). Two years mean yield indicated a sharp response to $\mathrm{N}$ application to the hybrid maize where as the effect of density found to non significant (Table 4). The two years mean showed that the grain yield of $11.1 \mathrm{t} /$ ha was obtained when the crop was fertilized with $180 \mathrm{~kg} \mathrm{~N} / \mathrm{ha}$ at the plant population of 83,383 plants /ha followed by the crop 
(10.69 t/ha) supplied with $120 \mathrm{~kg} \mathrm{~N}$ and with 66,666 plants /ha (Figure 4). Lowest grain yield of $8.14 \mathrm{t} / \mathrm{ha}$ was recorded when the crop was supplied only with $60 \mathrm{~kg} \mathrm{~N}$ and at the plant population of 55,555 plants /ha. Highest yield increase of $36.36 \%$ was observed over D1N1 when the crop was supplied with highest level of $\mathrm{N}$ and highest population of maize plant (D3N3, Table 4). It is noticed that highest density mean of $10.08 \mathrm{t} /$ ha and highest $\mathrm{N}$ mean of $10.53 \mathrm{t}$ /hawas observed as shown in two way table means (Figure 4, Table 5).

Table 2. Growth and yield parameters of Rampur Hybrid-2 as affected by nitrogen levels and plant densities during the year 2008/09

\begin{tabular}{cccccc}
\hline Treatment nos. & $\begin{array}{c}\text { Treatment } \\
\text { combination }\end{array}$ & $\begin{array}{c}\text { Ear length } \\
(\mathrm{cm})\end{array}$ & $\begin{array}{c}\text { Kernel row/ } \\
\text { ear (nos.) }\end{array}$ & $\begin{array}{c}\text { Kernels /row } \\
(\text { nos.) }\end{array}$ & $\begin{array}{c}\text { Straw yield } \\
(\mathrm{t} / \mathrm{ha})\end{array}$ \\
\hline $\mathrm{T} 1$ & $\mathrm{D}_{1} \mathrm{~N}_{1}$ & 13.86 & 15.06 & 27.73 & 7.94 \\
$\mathrm{~T} 2$ & $\mathrm{D}_{1} \mathrm{~N}_{2}$ & 13.80 & 15.33 & 29.66 & 7.84 \\
$\mathrm{~T} 3$ & $\mathrm{D}_{1} \mathrm{~N}_{3}$ & 13.46 & 14.93 & 28.53 & 8.70 \\
$\mathrm{~T} 4$ & $\mathrm{D}_{2} \mathrm{~N}_{1}$ & 13.20 & 14.80 & 27.93 & 7.87 \\
$\mathrm{~T} 5$ & $\mathrm{D}_{2} \mathrm{~N}_{2}$ & 12.86 & 14.80 & 27.73 & 8.58 \\
$\mathrm{~T} 6$ & $\mathrm{D}_{2} \mathrm{~N}_{3}$ & 13.46 & 15.86 & 29.13 & 8.17 \\
$\mathrm{~T} 7$ & $\mathrm{D}_{3} \mathrm{~N}_{1}$ & 12.26 & 15.46 & 27.60 & 8.68 \\
T8 & $\mathrm{D}_{3} \mathrm{~N}_{2}$ & 12.60 & 15.46 & 26.60 & 8.84 \\
T9 & $\mathrm{D}_{3} \mathrm{~N}_{3}$ & 12.46 & 15.60 & 26.60 & 8.75 \\
Grand mean & & 13.11 & 15.25 & 27.94 & 8.37 \\
F-test & $\mathrm{D}$ & $*$ & $\mathrm{~ns}$ & $\mathrm{~ns}$ & $\mathrm{~ns}$ \\
& $\mathrm{~N}$ & $\mathrm{~ns}$ & $\mathrm{~ns}$ & $\mathrm{~ns}$ & $\mathrm{~ns}$ \\
LSD & $\mathrm{D} \times \mathrm{N}$ & $\mathrm{ns}$ & $\mathrm{ns}$ & $\mathrm{ns}$ & $\mathrm{ns}$ \\
& $\mathrm{D}$ & 0.925 & - & - & - \\
CV, \% & $\mathrm{N}$ & - & - & - & - \\
& $\mathrm{D} \times \mathrm{N}$ & - & - & - & - \\
& & 7.07 & 3.68 & & 12.75 \\
\hline
\end{tabular}

**Highly significant, *significant and ns, non-significant.

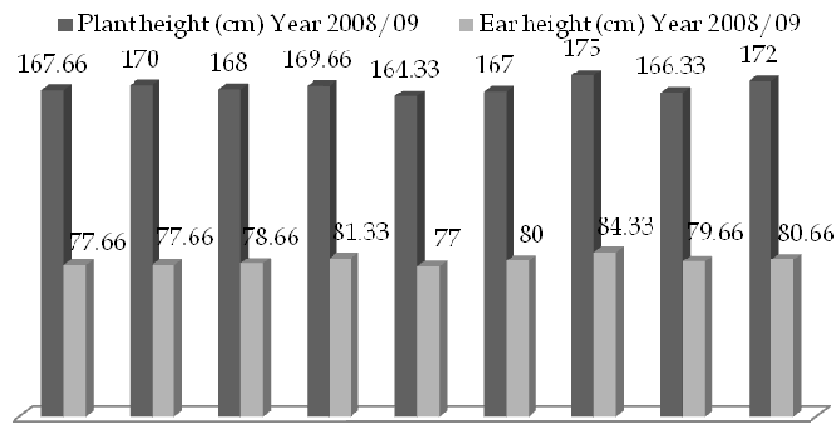

D1N1 D1N2 D1N3 D2N1 D2N2 D2N3 $\quad$ D3N1 D3N2 D3N3

Figure 1. Plant height and ear height influenced by varying treatment combination of plant densities and nitrogen rates in $\mathbf{2 0 0 8 / 0 9}$ 
Table 3. Effect of nitrogen rates on the growth and yield characters of hybrid maize planted at varying densities $(N \times D)$ during the years 2009/10 at NMRP farmland, Rampur

\begin{tabular}{cccccc}
\hline Treatment no. & $\begin{array}{c}\text { Treatment } \\
\text { combination }\end{array}$ & $\begin{array}{c}\text { Ear length } \\
(\mathrm{cm})\end{array}$ & $\begin{array}{c}\text { Kernel } \\
\text { rows /ear } \\
(\text { nos. })\end{array}$ & $\begin{array}{c}\text { Kernel/ row } \\
(\text { nos. })\end{array}$ & $\begin{array}{c}\text { Stover wt } \\
(\mathrm{t} / \mathrm{ha})\end{array}$ \\
\hline $\mathrm{T} 1$ & $\mathrm{D}_{1} \mathrm{~N}_{1}$ & 12.26 & 13.33 & 27.53 & 6.06 \\
$\mathrm{~T} 2$ & $\mathrm{D}_{1} \mathrm{~N}_{2}$ & 14.80 & 16.13 & 32.53 & 8.76 \\
$\mathrm{~T} 3$ & $\mathrm{D}_{1} \mathrm{~N}_{3}$ & 14.06 & 15.86 & 32.80 & 8.70 \\
T4 & $\mathrm{D}_{2} \mathrm{~N}_{1}$ & 13.33 & 15.00 & 30.13 & 6.83 \\
T5 & $\mathrm{D}_{2} \mathrm{~N}_{2}$ & 13.53 & 16.13 & 32.20 & 9.10 \\
T6 & $\mathrm{D}_{2} \mathrm{~N}_{3}$ & 14.33 & 16.53 & 32.60 & 8.90 \\
T7 & $\mathrm{D}_{3} \mathrm{~N}_{1}$ & 12.80 & 15.60 & 29.06 & 6.90 \\
T8 & $\mathrm{D}_{3} \mathrm{~N}_{2}$ & 13.53 & 16.00 & 30.60 & 8.80 \\
T9 & $\mathrm{D}_{3} \mathrm{~N}_{3}$ & 14.06 & 16.40 & 33.06 & 8.66 \\
Grand mean & & 13.63 & 15.66 & 31.17 & 8.08 \\
CV, \% & & 2.51 & 3.89 & 5.86 & 5.42 \\
F-test & Density, a & $\mathrm{ns}$ & $*$ & $\mathrm{~ns}$ & $\mathrm{~ns}$ \\
& Nitrogen, & $* *$ & $* *$ & $* *$ & $*$ \\
LSD, 0.05 & $\mathrm{a} \times \mathrm{b}$ & $*$ & $*$ & $\mathrm{~ns}$ & - \\
& $\mathrm{a}$ & - & 0.678 & - & - \\
& $\mathrm{b}$ & 0.355 & 0.626 & 1.875 & 0.448 \\
\hline
\end{tabular}

**Highly significant, *significant and ns, non-significant.

Plantheight (cm) Year 2009/10 - Ear height (cm) Year 2009/10

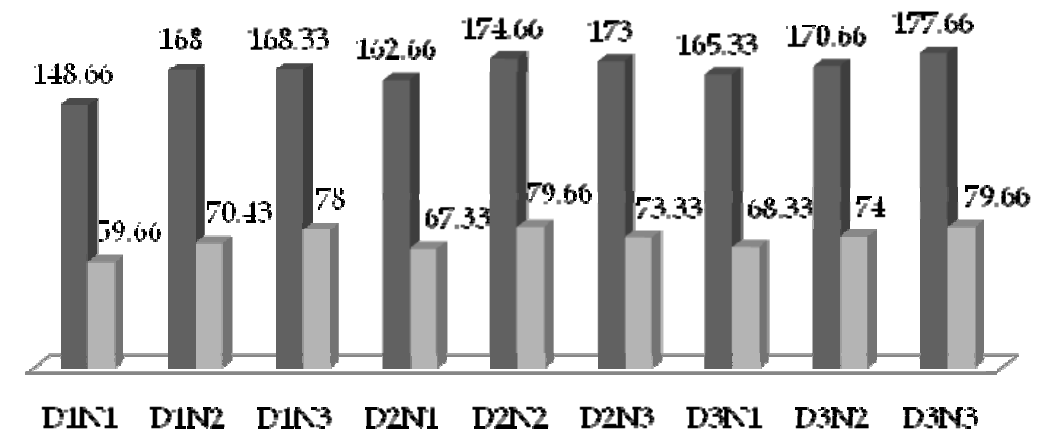

Figure 2. Plant height and ear height influenced by varying treatment combination of plant densities and nitrogen rates in 2009/10 
Table 4. Responses to $\mathrm{N}$ application for the grain production of hybrid variety during the years 2008/09 and 2009/10

\begin{tabular}{llllll}
\hline Treatment & $\begin{array}{l}\text { Treatment } \\
\text { combination }\end{array}$ & $\begin{array}{l}\text { Rampur } \\
\text { Hybrid } \\
(2008 / 09)\end{array}$ & $\begin{array}{l}\text { Rampur } \\
\text { Hybrid } \\
(2009 / 10)\end{array}$ & $\begin{array}{l}\text { Two-years } \\
\text { mean } \\
\text { grain yield } \\
\text { ( /ha) }\end{array}$ & $\begin{array}{l}\text { Increment } \\
\text { over } \\
\text { D1N1 } \\
\text { control) }\end{array}$ \\
\cline { 3 - 6 } & & $\begin{array}{l}\text { 1000 grain } \\
\text { wt }(\mathrm{g})\end{array}$ & $\begin{array}{l}1000 \text { grain } \\
\mathrm{wt}(\mathrm{g})\end{array}$ & Increase $(\%)$ \\
\hline $\mathrm{T} 1$ & $\mathrm{D}_{1} \mathrm{~N}_{1}$ & 407.78 & 410.66 & 8.14 & 00.00 \\
$\mathrm{~T} 2$ & $\mathrm{D}_{1} \mathrm{~N}_{2}$ & 438.12 & 445.33 & 9.90 & 21.62 \\
$\mathrm{~T} 3$ & $\mathrm{D}_{1} \mathrm{~N}_{3}$ & 472.37 & 456.33 & 10.02 & 23.09 \\
T4 & $\mathrm{D}_{2} \mathrm{~N}_{1}$ & 440.77 & 425.33 & 8.98 & 10.31 \\
T5 & $\mathrm{D}_{2} \mathrm{~N}_{2}$ & 473.41 & 456.66 & 10.69 & 31.32 \\
T6 & $\mathrm{D}_{2} \mathrm{~N}_{3}$ & 482.16 & 477.00 & 10.48 & 28.74 \\
T7 & $\mathrm{D}_{3} \mathrm{~N}_{1}$ & 424.10 & 410.66 & 8.52 & 04.66 \\
T8 & $\mathrm{D}_{3} \mathrm{~N}_{2}$ & 463.88 & 448.33 & 10.63 & 30.58 \\
T9 & $\mathrm{D}_{3} \mathrm{~N}_{3}$ & 474.73 & 456.33 & 11.10 & 36.36 \\
Grand mean & & 453.03 & 442.96 & 09.828 & \\
F-test & $\mathrm{D}$ & $*$ & $* *$ & $\mathrm{~ns}$ & \\
& $\mathrm{~N}$ & $* *$ & $* *$ & $* *$ & \\
LSD & $\mathrm{D} \times \mathrm{N}$ & $\mathrm{ns}$ & $\mathrm{ns}$ & $\mathrm{ns}$ & \\
& $\mathrm{D}$ & 19.27 & 10.06 & - & \\
CV, \% & $\mathrm{N}$ & 19.27 & 10.06 & 0.809 & \\
\hline
\end{tabular}

**Highly significant, *significant and ns, non-significant

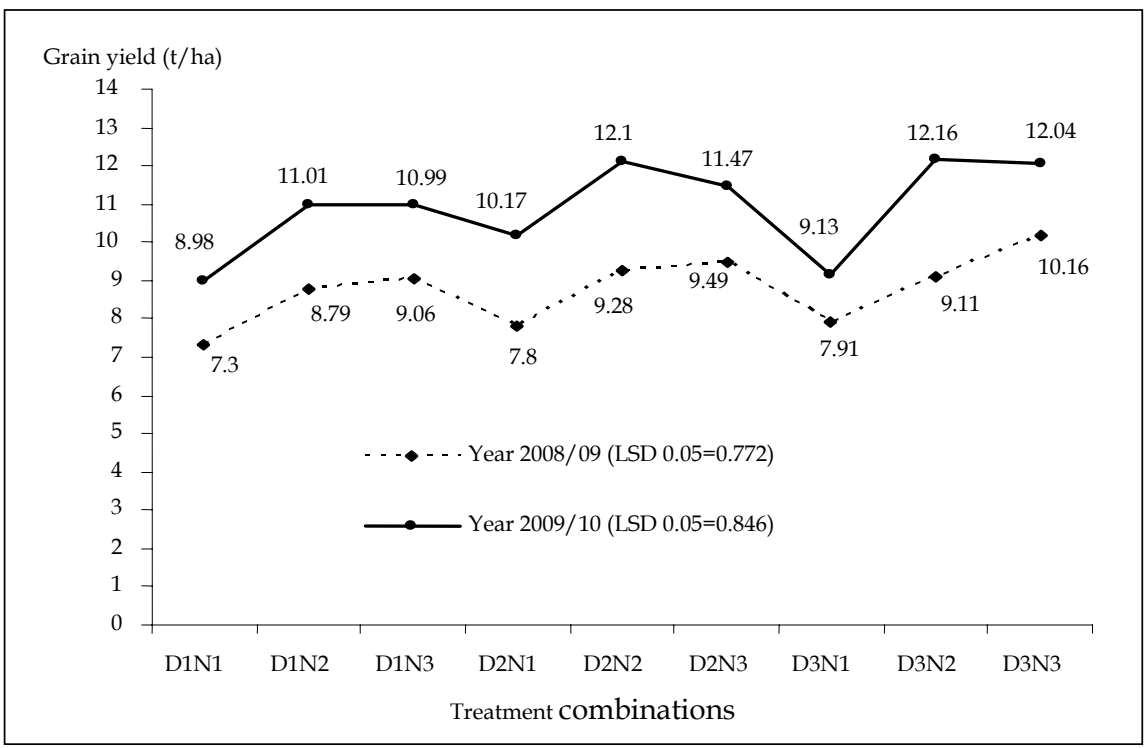

Figure 3. Grain yield of maize influenced by nitrogen and plant density (two years mean) 38 


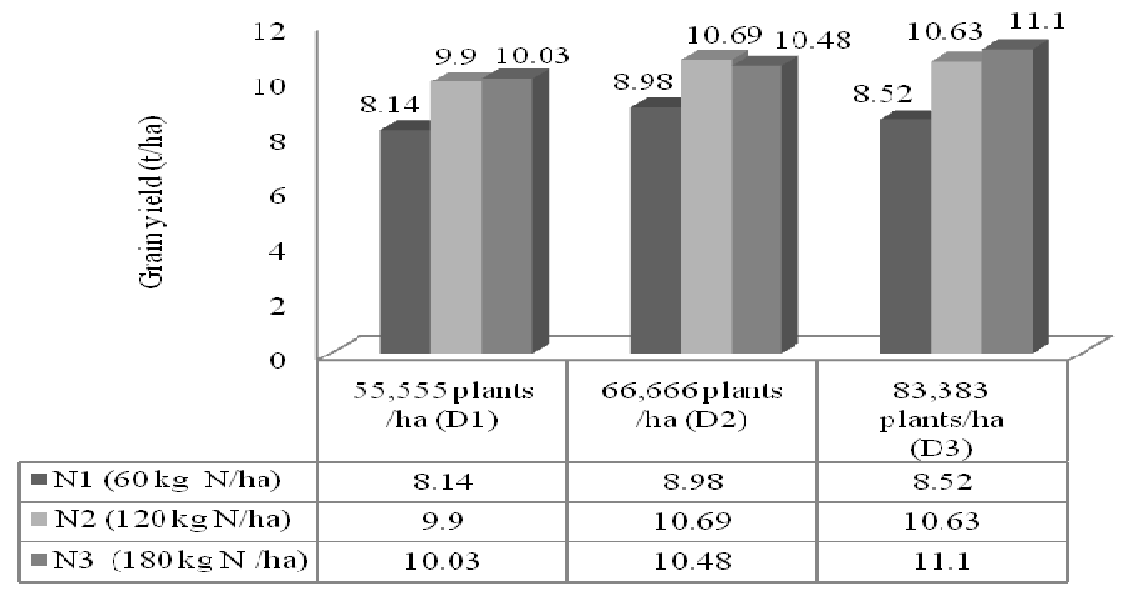

Figure 4. Graphical presentation of grain yield (two years mean) influenced by plant population and nitrogen rates

Table 5. Treatment means from two way table of grain yield as affected by nitrogen and plant densities

\begin{tabular}{lc}
\hline Treatment means & Grain yield $(\mathrm{t} / \mathrm{ha})$ \\
\hline Nitrogen rates & \\
$\mathrm{N}_{1}(60 \mathrm{~kg} \mathrm{~N} / \mathrm{ha})$ & 8.54 \\
$\mathrm{~N}_{2}(120 \mathrm{~kg} \mathrm{~N} / \mathrm{ha})$ & 10.04 \\
$\mathrm{~N}_{3}(180 \mathrm{~kg} \mathrm{~N} / \mathrm{ha})$ & 10.53 \\
Densities & \\
$\mathrm{D}_{1}(55,555$ plants $/ \mathrm{ha})$ & 9.35 \\
$\mathrm{D}_{2}(66,666$ plants $/ \mathrm{ha})$ & 10.05 \\
$\mathrm{D}_{3}(83383$ plants $/ \mathrm{ha})$ & 10.08 \\
\hline
\end{tabular}

Soil test result showed that $\mathrm{pH}$ of the experimental plot was found slightly decreased compared to that of composite sample taken before crop planting $(5.3 \mathrm{pH})$. On the contrary the organic matter (OM) content of soil after crop harvest was observed to be increased (2.5 to $2.05 \%)$ than the OM level before crop planting (2.0\%). Nitrogen, phosphorus and potassium content of soil at crop planting and after the crop harvest has been shown in Table 6. 
Table 6. Physico-chemical properties of soil at the experimental plots before crop planting (composite sample) and after crop harvest (treatment wise) during the year 2008/09 and 2009/10 (two years mean)

\begin{tabular}{ccccccc}
\hline Treatments & $\begin{array}{c}\text { Soil } \\
\text { texture }\end{array}$ & $\begin{array}{c}\mathbf{p H} \text { Scale } \\
\mathbf{( 1 - 1 4} \text { units) }\end{array}$ & $\begin{array}{c}\text { Organic } \\
\text { matter } \\
\mathbf{( \% )}\end{array}$ & $\mathbf{N ~ ( \% )}$ & $\left.\mathbf{P}_{\mathbf{2}} \mathbf{O}_{\mathbf{5}} \mathbf{( k g} / \mathbf{h a}\right)$ & $\begin{array}{c}\mathbf{K}_{\mathbf{2}} \mathbf{O} \\
\mathbf{( k g} / \mathbf{h a})\end{array}$ \\
\hline T1 & Silt & 4.70 & 2.40 & 0.117 & 357.52 & 163 \\
T2 & loam & 4.99 & 2.50 & 0.122 & 377.18 & 160 \\
T3 & & 4.98 & 2.50 & 0.121 & 342.12 & 191 \\
T4 & & 4.94 & 2.30 & 0.115 & 371.93 & 206 \\
T5 & & 4.80 & 2.30 & 0.115 & 383.84 & 131 \\
T6 & & 4.93 & 1.99 & 0.099 & 387.39 & 128 \\
T7 & & 5.03 & 2.50 & 0.118 & 399.21 & 148 \\
T8 & & 5.00 & 2.35 & 0.104 & 399.12 & 143 \\
T9 & & 4.90 & 2.05 & 0.102 & 365.24 & 137 \\
Composite & Silt & 5.30 & 2.00 & 0.100 & 359.42 & 161 \\
sample & loam & & & & & \\
\hline
\end{tabular}

Note. P and K was analyzed at Soil Science Division, NARC, Khumaltar and soil texture,OM and $\mathrm{N}$ content were analysed at NMRP soil laboratory, Rampur, Chitwan.

\section{Conclusion}

The effect of densities on the plant growth parameters were observed to be non significant for the both years $(2008 / 09,2009 / 10)$ but the effect of $\mathrm{N}$ on plant growth was observed to be highly significant in the $2^{\text {nd }}$ year but not in the first year. The highest 1000 grain wt $(482.16 \mathrm{~g})$ was recorded in the first year when the crop was supplied with $180 \mathrm{~kg} \mathrm{~N}$ and the plant population of 66,666 plants /ha. Similarly this level of N and density produced the highest 1000 grain wt (477.0 g) in the second year (2009/10). Two years grain yield mean revealed that highest grain yield of 11.10 $\mathrm{t} / \mathrm{ha}$ was recorded when the crop was supplied with $180 \mathrm{~kg} \mathrm{~N}$ and 83,383 plants/ha which was $36.36 \%$ higher than those produced by $60 \mathrm{~kg} \mathrm{~N}$ at 55,555 plants /ha $(8.14 \mathrm{t} / \mathrm{ha})$. It is suggested that high dose of $\mathrm{N}(180 \mathrm{~kg} \mathrm{~N} / \mathrm{ha})$ and high plant density (83,383 plants /ha) could help to increase Rampur Hybrid-2 maize grain yields.

\section{References}

Adhikary, BH and BR Baral. 2010. Effects of different rates of nitrogen and plant densities on hybrid maize.PP.64-65. In Annual Report for the Year 2009/10. National Maize Research Program (NMRP), NARC, Rampur, Chitwan, Nepal.

Adhikary, BH, DP Sherchan and DD Neupane. 2004. Effects of N levels in the production of maize planted at varying densities in the Chitwan valley. In. Proc. of the $24^{\text {th }}$ National Summer Crop Research Workshop on maize research and production in Nepal organized by NMRP, NARC, June 28-30, 2004. Kathmandu, Nepal. Pp 216-219.

Koirala KP, KK Lal and MM Palikhe. 1977. Report on maize varieties com densities trial. In Proc. of the $4^{\text {th }}$ National Maize Development Workshop, January 9-13, 1977. Pp 52-57. 
Sen, CK and BR Sthapit.1982. Study on intercropping of finger millet with maize in the western hills of Nepal. IAAS Journal 3(1). 37-42.

Sharma, D, D Chaudhary and R Yadav. 2004. Hybrid maize development for highly potential production system of Nepal. In. Proc. of the $24^{\text {th }}$ National Summer Crop Research Workshop on Maize Research and Production in Nepal organized by NMRP, NARC, June 28-30, 2004. Kathmandu Nepal. Pp 216-219.

Singh, C.1983. Modern techniques of raising field crops. C Singh (ed.), G.B. Panta University of Agriculture and Technology, Pantanagar, Oxford and IBH Publishing Co. Pvt. Ltd. New Delhi, India. Pp 74-94

Swanson, ER, CR Taylor and LF Welch. 1973. Economically optimum levels of nitrogen fertilization for corn. an analysis based on experimental data (1966-1971). Illinois, Agri. Economics 13 (2). 16-25. 